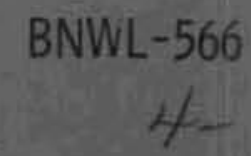

\title{
PRELIMINARY RADIOLOGICAL CONSIDERATIONS INVOLVED WITH THE EXAMINATION OF IRRADIATED FFTF FUEL ELEMENTS
}

A. J. Stevens, F. Swanberg, and E. C. Watson

December 1967

\section{AEC RESEARCH \& DEVELOPMENT REPORT}




\section{LEGAL NOTICE}

This report was prepared as an account of Government iponsorsd work. Nelither the United States, nor the Commistion, nor ony perzon acting on betholf of the Commission.

A. Makes any waranty or representation, expressed or implled, with reipect to the accuracy, complateness, or usefuiness of the infarmation contained in this report, or that the use of any Informetipn, apparatos, methed, or process disclosed In this roport moy not infringe privatsly omned rights or

B. Astumei cany. liabilities with respect to the vie of of for domoges resulting from the use of any intarmation opporatut, method, or process disclosed in this repont.

At used in the obove, "person acting on beholf of the Cammissian" includes any employee or contractor of the Commisston, on employee of such contractor, to the extent that such employes or confrector of the Commission. ar employse of weh contractor prepates, ditseminates, of propides occess to, any infarmation pursuant to his employment ar controet with the Commission, ar his employment with wech contractor:

\section{PACIFIC NORTHWEST LABORATORY \\ RICHIAND, WASHINGION \\ operated by \\ BATTELLE MEMORIAL INSTITUTE}

for the

UNITED STATES ATOMIC ENERGY COMMISSION UNDER CONTRACT AT(45.1)-183O 


\title{
33679000606956
}

\author{
BNWL - 566 \\ UC-80, Reactor Technology
}

\begin{abstract}
PRELIMINARY RADIOLOGICAL CONSIDERATIONS INVOLVED WITH THE EXAMINATION

OF IRRADIATED FFTF FUEL ELEMENTS
\end{abstract}

\section{By}

A. J. Stevens, F. Swanberg, and E. C. Watson

Nuclear Safety Section

Environmental Health Department

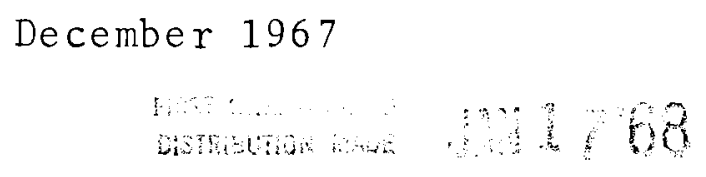

PACIFIC NORTHWEST LABORATORY

RICHLAND, WASHIINGTON 
Printed in the United States of America Available from

Clearinghouse for Federal Scientific and Technical Information National Bureau of Standards, U.S. Department of Commerce Springfield, Virginia 22151

Price: Printed Copy $\$ 3.00 ;$ Microfiche $\$ 0.65$ 
BNWL - 566

TABLE OF CONTENTS

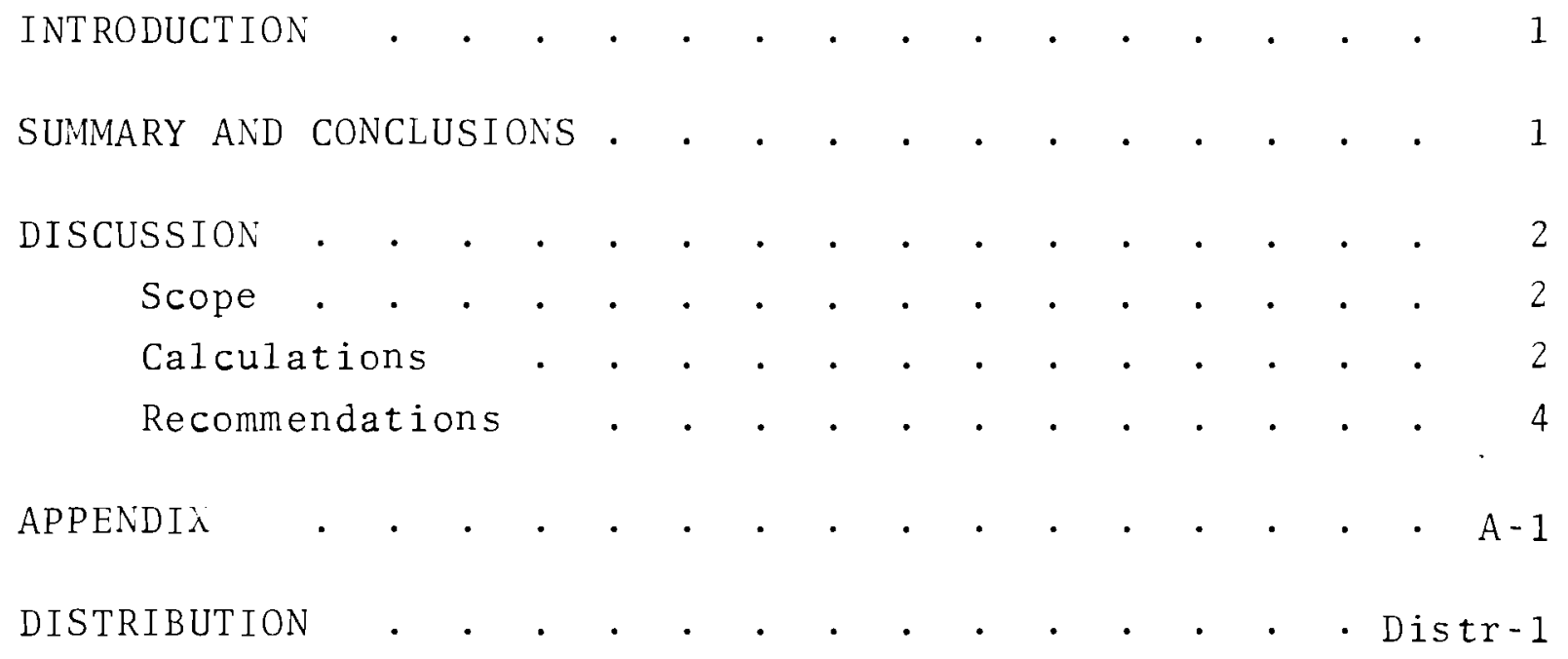




\title{
PRELIMINARY RADIOLOGICAL CONSIDERATIONS INVOLVED WITH THE EXAMINATION OF IRRADIATED FFTF FUEL ELEMENTS
}

\author{
A. J. Stevens, F. Swanberg, and E. C. Watson
}

\section{INTRODUCTION}

This report describes the determination of appropriate criteria for contamination control in the Fast Flux Test Facility (FFTF) which will allow the processing and examination of the FFTF fue 1 for any period up to 50 days after discharge. Knowledge of the relative abundance of radionuclides is required to establish design bases which can be used for guidance in planning adequate decontamination equipment and contamination control measures, including ventilation systems. Selected isotopes of the fission product inventories are used to establish a gross beta-gamma activity estimate as a function of fuel exposure, and time since irradiation. Initially, it was assumed that the ratio of beta-gamma activity to alpha activity might be a useful index for controlling alpha contamination based on beta-gamma sensitive air monitoring of the FFTF fuel examination facilities. This study shows, however, that alpha sensitive air monitoring equipment will be necessary.

\section{SUMMARY AND CONCLUSIONS}

Under certain conditions of fuel exposure, and time since irradiation, plutonium will be present in quantities which require that the control criteria for design of the facility provide maximum personnel protection to prevent internal deposition of plutonium. It is recommended that confinement systems be utilized for transfer, examination, and processing of irradiated FFTF fuel. Continuous alpha sensitive air monitoring will be required in addition to similar equipment sensitive to beta-gamma emitting fission products. 


\section{DISCUSSION}

\section{$\underline{\text { SCOPE }}$}

The task consisted of revising an existing computer code, used for calculating the fission product inventories produced by the thermal fission of ${ }^{235} \mathrm{U}$ and ${ }^{239} \mathrm{pu}$ as a function of fuel irradiation history and decay time since irradiation, so that it is applicable to fast fission produced inventories. The accuracy of the calculated inventories and the estimated release of volatile fission products is limited by the precision of existing data. These calculated inventories are used for developing guidance for filtration and gaseous decontamination equipment in the ventilation system of FFTF fuel examination facilities. In addition, selected isotopes of the fission product inventory are used to determine a "gross" beta-gamma activity value. This value can then be compared to the plutonium alpha activity value as a function of fuel irradiation history and decay time.

\section{CALCULATIONS}

The beta-gamma to alpha activity ratio after fifty days cooling has been calculated as a function of irradiation time for three potential compositions of FFTF fuel. These are:

Case I $21.46 \%$ enrichment with blanket Pu. Balance depleted $U(0.3 \% 235 U)$

Case II 29.47\% enrichment with blanket Pu. Balance depleted U $\left(0.3 \%^{235} \mathrm{U}\right)$

Case III $30.67 \% \mathrm{Pu}, 19.82 \%$ fissile enrichment with PWR Pu. Balance depleted U $(0.3 \% 235 \mathrm{U})$

The resulting activity ratios for each of the three cases is shown in Figure 1 . 


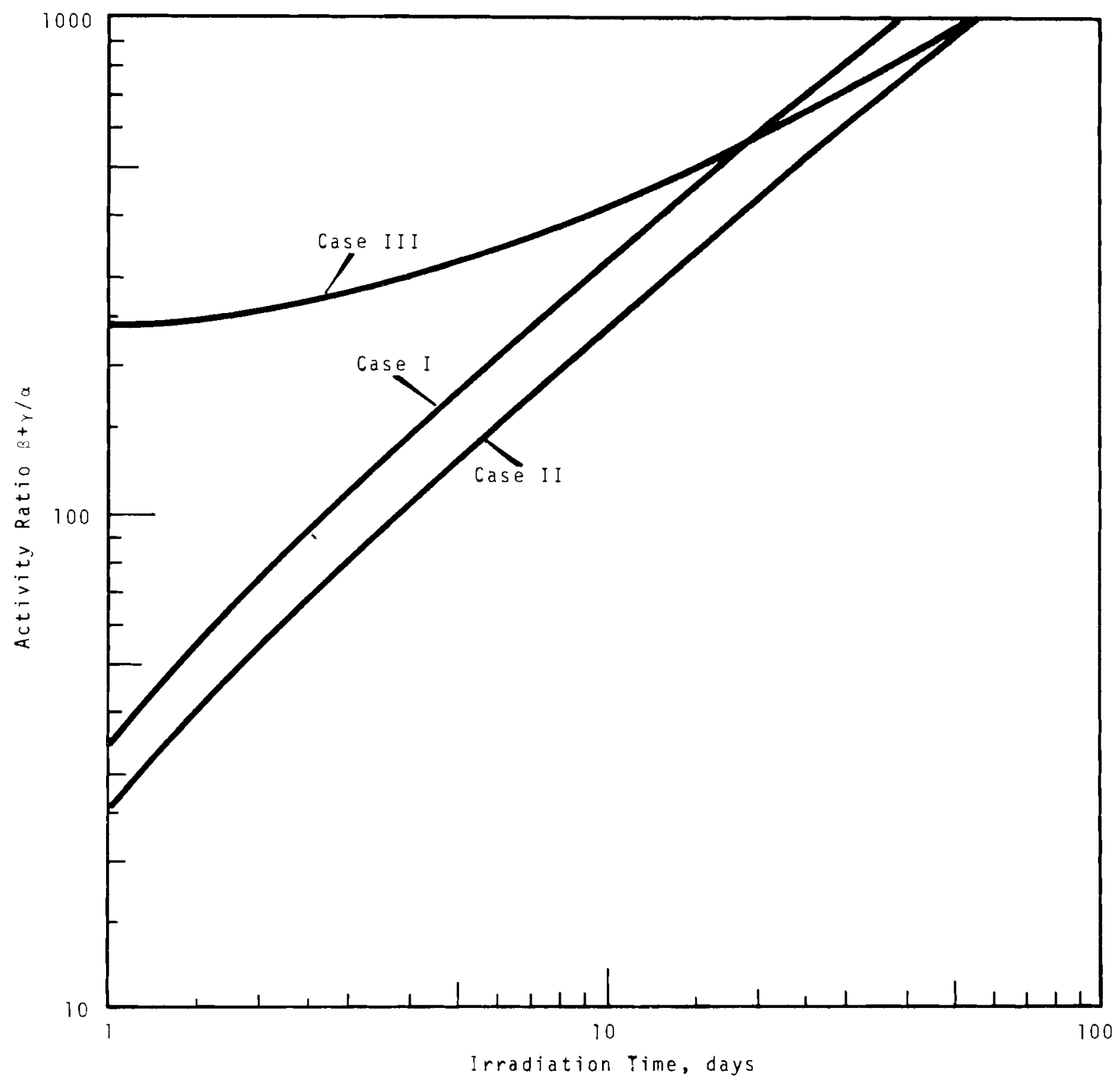

FIGURE 1. Ratio of Beta-Gamma Activity to Alpha Activity after 50 Days Cooling Time as a Function of Fuel Irradiation Time 
The beta-gamma to alpha activity ratio must be weighted in accordance with the maximum permissible dose for the organs of interest and the maximum permissible concentration in air [(MPC)air] for each radionuclide and for the several body organs of interest. In this way, the appropriate criteria for radiological protection purposes are developed as shown in the attached appendix.

Estimates of fuel inventories, for irradiation times from 1 to 150 days and after a cooling time of 50 days, have been used to determine that $\beta$ emitters are not the primary contributors to bone dose and cannot be relied upon exclusively to evaluate air samples whenever mixtures of $\beta$ emitters and plutonium may be present.

\section{RECOMMENDATI ONS}

Control of the hazards of plutonium processing is based on the premise that exposure of personnel should be as 1 ow as possible. When taken into the human body, plutonium deposits predominately in the skeleton, and if deposited in sufficient quantities, may produce damage many years later. The amount of plutonium absorbed from the gastrointestinal tract is only about 0.01 to $0.003 \%$ of an orally administered dose. A small amount of plutonium can be absorbed through the intact skin. Contaminated cuts and puncture wounds are an important source of exposure for radiation workers. Absorption into the blood stream from the lung can be as much as $20 \%$ of the quantity inhaled, depending upon physical and chemical properties of plutonium. Because lung absorption is an important route of entry into the body, rigorous closed systems are employed in plutonium processing. Once in the body, ${ }^{239} \mathrm{Pu}$ is excreted at an extremely slow rate. The maximum permissible body burden of plutonium is established by comparison with ${ }^{226} \mathrm{Ra}$ and is that amount resulting in a dose equivalent to $0.1 \mu \mathrm{Ci}$ of fixed $226 \mathrm{Ra}$. 
The amount of plutonium present as air-borne contaminants in a working area is determined by a continuous air sampling program. Respiratory protection is required at any time the amount of air-borne plutonium activity exceeds the maximum permissible concentration in air (MPC) air, i.e., $2 \times 10^{-12}$ $\mu \mathrm{Ci} / \mathrm{cm}^{3}$.

Chronic exposure to air-borne contamination should not exceed the maximum permissible concentrations of radionuclides in air for occupational exposure as specified in ICRP Report II Permissible Dose for Internal Radiation.* In keeping with ICRP recommendations, AEC regulations, and Battelle-Northwest policy of minimizing all radiation exposure and avoiding al1 internal deposition insofar as possible, chronic exposure to air-borne contamination which exceeds $1 / 20$ of the ICRP Report II values is to be avoided.

A separate vacuum system should be installed and air sampling equipment and outlets provided wherever air-borne contamination can be expected to exceed $1 / 10$ of the ICRP Report II value. A pressure drop of $20 \mathrm{in.} \mathrm{of} \mathrm{water} \mathrm{is} \mathrm{required} \mathrm{at} \mathrm{each}$ standard sampling head with filter paper in place. This pressure drop is to be maintained with all sample outlets in simultaneous use.

Fresh air outlets should be installed throughout the facility for use where air-borne contamination can be expected to exceed 20 times the ICRP Report II 1 imits for ${ }^{239}$ Pu.

Air balance should be maintained at all times so that air flow is from nonradioactive zones to moderately radioactive zones to highly radioactive zones, rooms, cells, and hoods. Air pressure differentials between nonradioactive and radioactive

* Recommendations of the International Commission on Radiological Protection. ICRP Publication 2. 
zones should be maintained between $1 / 10$ and $1 / 4$ in. of water. These pressure differentials should be maintained by using air locks at all entrances and exits. The highest air pressure within the facility should be negative with respect to the outside atmosphere. The air pressure differential between hoods and rooms, or cells and rooms, should be between minus $1 / 4$ in. and minus 1 in. of water. The air exhaust system of each room, hood, or cell should be capable of maintaining a 1 inear flow rate of $150 \mathrm{ft} / \mathrm{min} \pm 25 \mathrm{ft} / \mathrm{min}$ through any normal opening. Appropriate alarms should be provided to signal the loss of building air balance.

Exhaust air from a cell or hood should be filtered first by a roughing filter to protect the downstream high efficiency (99.95\% for $0.3 \mu$ particles) filter, both readily changeable. All process air entering the main exhaust system should be filtered at the point of entry with a high efficiency filter, readily changeable. Air leaving a hood or cell is filtered to retard contamination of the exhaust plenum and at the same time to confine the contamination to a given hood or cell. Other types of air clean-up systems are required for volatile wastes such as iodine, cesium, antimony, ruthenium, tellurium and others.

Provisions should be made for sampling exhaust air downstream from each high efficiency filter. To isolate and identify the source of contamination entering the exhaust system, the capability to sample the exhaust air from each hood or ce11 is required. To find a defective filter requires the sampling of exhaust air after each filter bank. Prompt detection and replacement of defective filters are required to maintain system efficiency.

Air locks or equivalent systems should be employed for transfer of materials into, out of, or between cells or hoods 
to assure complete contamination control and minimize personnel radiation exposure. Specially-shielded equipment, remotelyoperated equipment, and high integrity confinement systems should be utilized in the control of radiation exposure and contamination spread.

The design arrangement of the inert gas recirculating system should provide for possible build-up of radiation in equipment such as fans, purification components, coolers, and ducts. Consideration should be given to removal of the halogens in the recirculating gas.

Amounts of radioactive materials that require special shielding and handling should be contained by at least three independent barriers between the source and the atmosphere for personnel passageways, and by at least two independent barriers for nonpassageway routes. Three independent barriers, such as a process cell and a room with an air lock entrance and exit, which requires correct usage, are required to ensure control of contamination spread through entrance and exit routes. For nonpassageway routes, a cel1 wall and sealed building wall provide the necessary confinement. It is necessary that all contamination be retained within the first barrier during routine operations.

The design of hoods, cells, and process equipment should consider future decontamination requirements. Rough surfaces, square corners, cracks or crevasses, and absorbent materials should be avoided. Disposable linings, covers, coatings, or easily decontaminated surfaces are used for ease of operation. Some equipment will have to be made of durable material to withstand stringent decontamination procedures and reagents.

Radioactive liquid and gas transfer facilities should be such that back-up in transfer lines or associated actuating lines is positively prevented. These lines should not pass 
directly into occupied work locations; however, if this cannot be prevented, the lines should be enclosed providing a double barrier between the liquid or gas and the work area.

Standardized parts result in simplified maintenance and reduce processing delays for alterations. Designs should be comprehensive in anticipating modifications and maintenance requirements. Standard components that minimize delays in maintenance or modification will result in reduced radiation exposure and contamination spread.

A11 normal entrances and exits to radioactive areas should be through change rooms. Step-off pad procedures should be used between potentially contaminated and noncontaminated areas. Appropriate radiation monitoring instruments should be provided at each exit from a radioactive area. If emergency exits are required from highly contaminated areas directly to "clean" areas, an air lock should be provided at these exits. Personnel traffic control should limit access to sources of radiation and contamination.

Human action to detect malfunction or abnormal radiological conditions is usually possible only after the fact. Risk to the safety of operating personnel and equipment is encountered if detection of malfunctions requires human action. Prompt awareness of difficulties should be provided by automatic detection equipment, such as annunciators and alarms. 


$$
\text { APPENDIX A }
$$

CRITERION FOR PLUTONIUM FUEL PROCESSING BASED

ON $\beta-\gamma / \alpha$ RATIOS 


\section{APPENDIX \\ CRITERION FOR PLUTONIUM FUEL PROCESSING BASED ON $\beta-\gamma / \alpha$ RATIOS}

The dose rate to an organ of reference can be expressed by:

$$
d_{j}=M_{j} \sum_{i}\left[\frac{\rho_{i}}{(M P C P)_{j}^{i}}\right]_{a i r}+d_{j}^{\gamma}+d_{j}^{n}
$$

where:

$$
\mathrm{d}_{\mathrm{j}}=\text { weekly dose to organ j, rems/week }
$$

$$
\begin{aligned}
M_{j}= & \text { maximum permissible weekly dose (average) to } \\
& \text { organ } j \text {, rems/week } \\
P_{i}= & \text { concentration of radionuclide } i, \frac{\mu \mathrm{Ci}}{3}
\end{aligned}
$$$$
\mathrm{MPC}_{j}^{i}=\text { maximum permissible concentration of radio- }
$$
nuclide $i$ for organ $j, \mu \mathrm{Ci} / \mathrm{cm}^{3}$

$$
\begin{aligned}
d_{j}^{\gamma=} & \text { weekly dose (average) to organ } j \text { from } \\
& \text { r-radiation, rems/week } \\
d_{j}^{n}= & \text { weekly dose (average) to organ } j \text { from } \\
& \text { neutrons, rems/week }
\end{aligned}
$$

Now, the acceptability of a mixture of air-borne radionuclides is determined by:

$$
\sum_{i}\left[\frac{\rho_{i}}{(M P C)_{j}^{i}}\right]_{\text {air }} \leq \frac{d_{j}-d_{j}+d_{j}^{n}}{M P D_{j}}
$$


In processing plutonium fuels, the mixture is composed of both $\alpha$ and $\beta$ and/or $\gamma$ emitters. Because of ease of detection and measurement, mixtures of fuel and fission products in which B-emitters are the major contributor to the dose would result in a more efficient air contamination control program. This can be achieved by establishing limits for the minimum time of fuel irradiation and then processing these fuels within a specified cooling time after shutdown. To determine when the exposure to $\beta$-emitters is controlling, it is convenient to examine the ratio of $\beta$-emitters to $\alpha$-emitters.

In Equation (2), the summation term can be expressed by the identity:

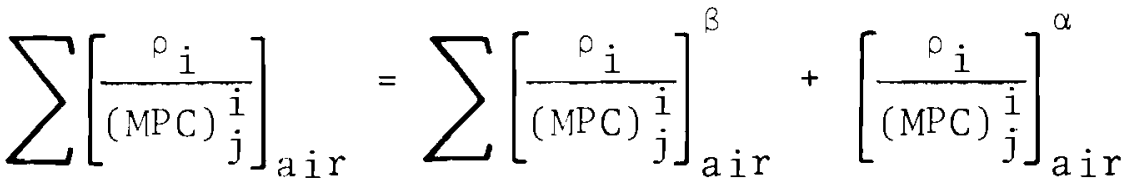

i

or

$$
\sum_{i}\left(M_{j}^{i}\right)_{a i r}=\sum\left(M_{j}^{i}\right)_{\text {air }}^{\beta}+\sum\left(M_{j}^{i}\right)_{a i r}^{\alpha}
$$

where: $\quad\left(M_{j}^{i}\right)_{\text {air }}=\frac{\rho_{i}}{(M P C) \frac{j}{j}}$

and:

$$
\left(M_{j}^{i}\right)_{\text {air }}^{\beta}=\left[\frac{o_{i}}{(M P C) \frac{i}{j}}\right]_{a i r}^{\beta} \text { for } \beta \text {-emitters }
$$

and:

$$
\left(M_{j}^{i}\right)_{\text {air }}^{\alpha}=\left[\frac{\rho_{i}}{(M P C)}\right]_{\text {air }}^{\alpha} \text { for } \alpha \text {-emitters }
$$

For this analysis, it will be assumed that $\left(\mathrm{M}_{j}^{\mathrm{i}}\right)_{\text {air }}$ will be limited by $\beta$-emitters whenever $\left(M_{j}^{i}\right)_{\text {air }}^{\alpha} \leq 0.1\left(M_{j}^{i}\right)_{\text {air }}^{\beta}$, 
or $: \frac{\sum\left(M_{j}^{i}\right)_{\text {air }}^{\beta}}{\sum\left(M_{j}^{i}\right)_{\text {air }}^{\alpha}}=10$

Now, let's examine the individual radionuclide air concentrations, $i . e ., o_{i}$. For a specified release to tlie room atmosphere. The air concentration can be expressed by:

$$
\rho_{i}=\frac{q_{i}}{v}
$$

where: $\quad q_{i}=$ quantity of radionuclide $i$ released -

and $\quad v=$ room air volume

When $q_{i}$ is in units of curies and $v$ in cubic meters, $\rho$ still has units of $\mu \mathrm{Ci} / \mathrm{cm}^{3}$

Substituting Equation (4) into Equation (3) yields;

$$
\sum_{i}\left(R_{j}^{i}\right)_{\text {air }}=\sum\left(R_{j}^{i}\right)_{\text {air }}^{\beta}+\sum\left(R_{j}^{i}\right)_{\text {air }}^{\alpha}
$$

Where now;

$$
R_{j}^{i}=\frac{q_{i}}{(M P C)_{j}^{i}} \quad ; \begin{aligned}
& \text { since the room air volume, } v \text { is } \\
& \text { common to all } R_{j}^{i} \text { values. }
\end{aligned}
$$

Thus, the ratio criterion becomes:

$$
\frac{\sum\left(R{ }_{j}^{i}\right)_{a i r}^{\beta}}{\sum_{i}^{i}\left(R{ }_{j}^{i}\right)_{a i r}^{\alpha}}=10
$$


. 


\section{DISTRIBUTION}

No. of

Copies

2

268

1

28

AEC Chicago Patent Group

G. H. Lee, Chief

R. K. Sharp, Rich1and Representative

AEC Division of Technical Information Extension

AEC Idaho Operations Office

C. W. Bil1s, Director

AEC Library, Washington

Division of Reactor Development and Technology

M. Shaiv, Director, RDT

Assistant Director for Nuclear Safety

Analysis and Evaluation Branch, RDT:NS

Environmental and Sanitary Engineering Branch, RDT : NS

Research and Development Branch, RDT:NS

Assistant Director for Plant Engineering, RDT

Applications and Facilities Branch, RDT:PE

Components Branch, RDT:PE

Instrumentation and Control Branch, RDT:PE

Systems Engineering Branch, RDT:PE

Assistant Director for Program Analysis, RDT

Assistant Director for Project Management, RDT

Liquid Metals Projects Branch, RDT:PM

FFTF Project Manager, RDT:PM (3)

Assistant Director for Reactor Engineering

Control Mechanisms Branch, RDT:RE

Core Design Branch, RDT:RE

Fue 1 Fabrication Branch, RDT:RE

Fue 1 Handling Branch, RDT:RE

Reactor Vessels Branch, RDT:RE

Assistant Director for Reactor Technology

Chemistry and Chemical Separations Branch, RDT : RT (2)

Fue1s and Materials Branch, RDT:RT

Reactor Physics Branch, RDT:RT

Special Technology Branch, RDT: RT

AEC Richland Operations Office

FFTF Project office

J. H. Krema (2)

Technical Information Library

Engineering and Construction Division 
No. of

Copies

1

AEC San Francisco Operations Office

Director, keactor Division

4

AEC RDT Site Representatives

Pacific Northwest Laboratory

P. G. Holsted

L. R. Lucas

A. D. Toth

4

AEC RDT Site Representatives

Argonne National Laboratory

Atomics International

Atomic Power Development Associates, Inc.

General Electric Company

2

Argonne National Laboratory

R. A. Jaross

LMFBR Program Office

3

Atomics Internationa1

D. F. Bunch

R. W. Dickinson

L. E. Glasgow

1

Atomic Power Development Associates, Inc.

B. V. D. Earris

2

Babcock and Wilcox Company

Atomic Energy Livision

S. H. Esleeck

T. P. Farre11

1

Battelie Nemorid1 Institute

3

2

4
Douglas United Nuclear, Inc.

Files (3)

General Dynamics Corporation

D. Coburn (2)

Genera1 Electric Company

$K$. Cohen (3)

B. Holfe 


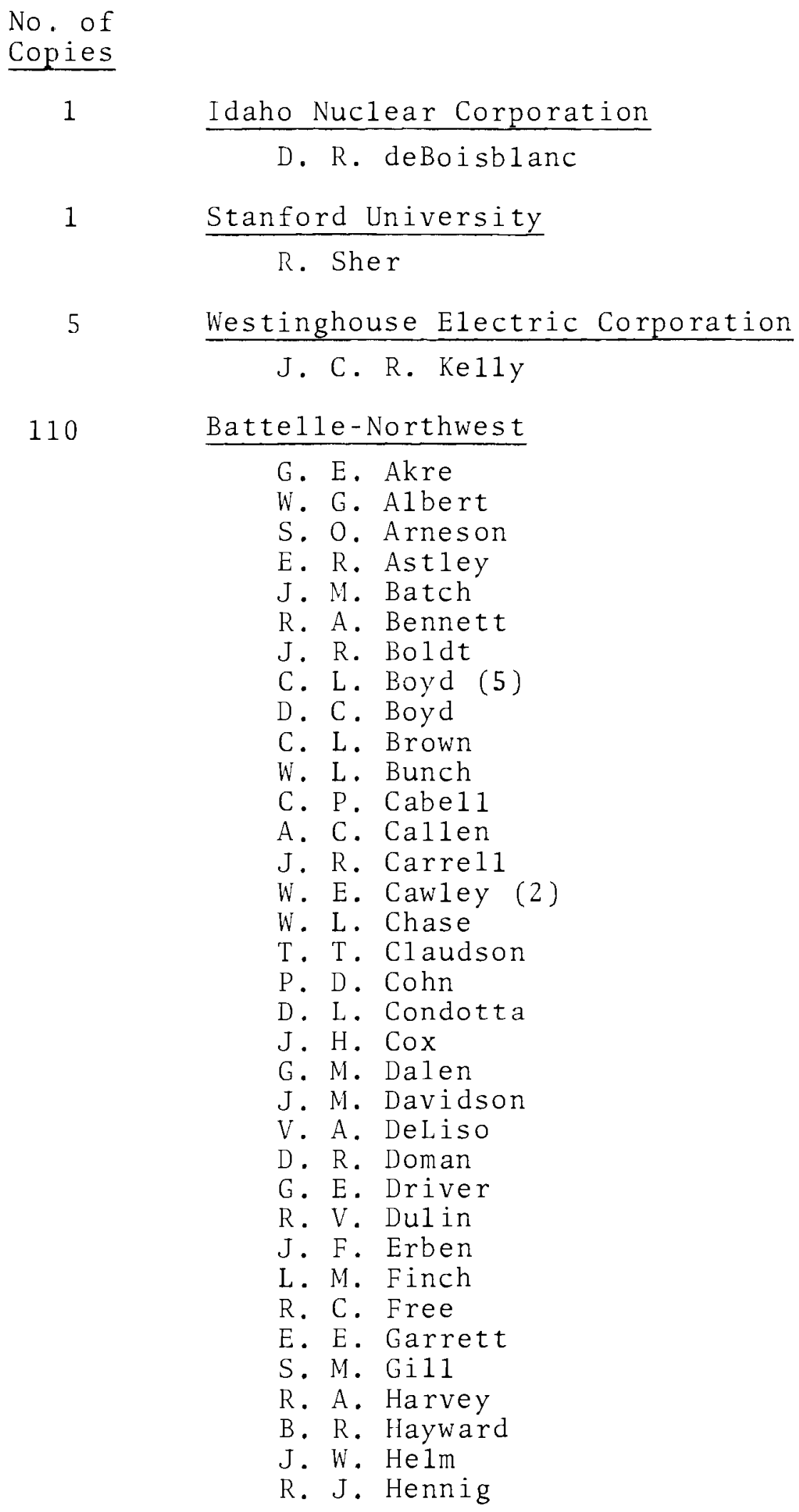


Batte1le-Northwest (contd)

G. M. Hesson

P. L. Hofmann

B. M. Johnson

H. G. Johnson

R. L. Junkins

A. R. Keene

$J$. H. Kinginger

D. D. Lanning

H. D. Lenkersdorfer

C. W. Lindenmeier

H. E. Little

W. W. Little

C. E. Love

W. B. McDonald

M. H. Meuser

R. A. Moen

C. A. Munro

D. M. Nero

M. G. Patrick

J. A. Perry

R. E. Peterson

W. E. Roake

J. D. Schaffer

F. H. Shade 1

D. W. Shannon

D. E. Simpson

C. R. F. Smith

R. J. Squires

A. J. Stevens (10)

G. H. Strong

F. Swanberg (5)

C. D. Swanson

J. C. Tobin

K. G. Toyoda

M. Voge 1

D. M. Walley

E. C. Watson (5)

J. H. Westsik

L. A. Whinery

R. D. Widrig

N. G. Wittenbrock

M. R. Wood

F. W. Woodfield

FFTF Files (2)

Technical Information Files

Technical Publications (2) 